\title{
МОРФОНОЛОГІЧНІ ПАРАМЕТРИ АФІКСІВ ВІДДІССЛІВНОГО СЛОВОТВОРЕННЯ В УКРАЇНСЬКІЙ МОВІ
}

Демешко I. M. Морфонологічні параметри афіксів віддієслівного словотворення в українській мові.

У статті 3'ясовано морфонологічні параметри префіксів, елементарних i складних суфіксів віддієслівних похідних. Розглянуто морфонологічно релевантні особливості іменникових, прикметникових та дієслівних афіксів в українській мові. Установлено, що фінальні елементи дієслівної основи, які зазнають змін під впливом ініціалі форманта, сигналізують про можливі морфонологічні операції (усічення, консонантні, вокалічні альтернації, нарощення суфіксальної чи кореневої морфем, модифікації наголосу) у віддієслівному похідному.

Ключові слова: словотвірна морфонологія, девербатив, афікс, суфікс, префікс, морфема, словотвірне гніздо, морфонологічна будова.

Демешко И. Н. Морфонологические параметры аффиксов отглагольного словообразования в украинском языке.

В статье установлено морфонологические параметры приставок, элементарных и сложных суффиксов отглагольных производных. Рассмотрены морфонологически релевантные особенности аффиксов существительных, прилагательных и глаголов в украинском языке. Установлено, что финальные элементы глагольной основы, которые испытывают изменения под влиянием (c) I. М. Демешко, 2015. $-68-$ 
инициали форманта, сигнализируют о возможных морфонологических операциях (усечение, консонантные, вокалические альтернации, наращивания суффиксальной или корневой морфем, модификации ударения) в отглагольном производном.

Ключевые слова: словообразовательная морфонология, девербатив, аффикс, суффикс, приставка, морфема, словообразовательное гнездо, морфонологическая структура.

Demeshko I. M. Morphonogical characteristics of affixes of verbal derivation in the Ukrainian language.

The article deals with the morphonological characteristics of prefixes, elementary and complex suffixes of verbal derivatives in the Ukrainian language. It examines the morphonologically relevant features of noun, adjective and verb affixes in the Ukrainian language. It was established that the final elements of the verbal stem, which are changing under the influence of formant initials, signals of possible morphonological operations (reduction, consonant and vocal alternations, lengthening of suffix or root morphemes, accent modification) in verbal derivatives.

Key words: derivational morphonology, verbal derivatives, affix, suffix, prefix, morpheme, morphonological structure, word-forming family, morphonological structure.

Опис словотвірної морфонології девербативів сучасної української літературної мови з огляду на ії функційний характер, динамічні процеси в мові, зрушення, що відбулися в ії корпусі протягом останнього часу, дає вагомі підстави визначення нових класифікаційних принципів морфонологічного аналізу девербативів. Питання внутрішньої організації слова, комплексний аналіз семантичних, словотворчих і граматичних ознак девербативів залишається актуальною проблемою граматики української мови. Новітня концепція моделювання девербативів української мови, спрямована на глибокий i багаторівневий аналіз морфонологічних операцій, відбиває їхню формальну кваліфікацію, окреслює семантичну та комунікативно-прагматичну специфіку девербативів субстантивного, вербального, ад’єктивного й адвербіального блоків.

Метою пропонованої розвідки є з'ясування морфонологічних параметрів префіксів, елементарних і складних суфіксів віддієслівних похідних, опис морфонологічно релевантних особливостей іменникових, прикметникових та дієслівних афіксів у морфонологічному аспекті. Досягнення поставленої мети передбачає розв'язання таких завдань: 1) з'ясування морфонологічних параметрів префіксів, елементарних i складних суфіксів віддієслівних похідних; 2) установити детермінанти морфонологічних перетворень у структурі похідних віддієслівних словотвірних гнізд; 3) розглянуто морфонологічно релевантні особливості іменникових, прикметникових та дієслівних афіксів в українській мові.

Матеріалом для дослідження послугували 2 тисячі самостійно $-69-$

๑) І. М. Демешко, 2015. 
укладених віддієслівних словотвірних гнізд із використанням тлумачних, словотвірних, етимологічних словників.

Морфонологічна проблематика розроблялася в працях Л. Блумфілда, Я. (І.) Бодуена де Куртене, О. Земської, В. Касевича, М. Крушевського, О. Кубрякової, Ю. Панкрата, О. Реформатського, М. Трубецького, Г. Улашина, В. Чурганової. У сучасному українському мовознавстві в межах словотвірної морфонології досліджено основи теорії морфонологічного опису (В. Горпинич), проблеми аглютинативності в словотворенні, сполучуваності на морфемних швах (Н. Клименко, Є. Карпіловська), закономірності реалізації морфонологічних явищ у системі словотвору (К. Городенська, М. Кравченко), морфонологічні процеси в системі іменників (Л. Комарова, Л. Кондакова) і словозміни дієслів української мови (І. Козленко), морфонологічні модифікації в процесі словозміни та словотворення прикметника (Л. Асіїв). На початку XXI ст. 3'являються праці, присвячені дослідженню морфонологічних процесів у словозміні та словотворі староукраїнської мови другої половини XVI-XVIII ст. (Н. Русаченко), дериваційної морфонології російських говорів (О. Антипов). Спроби описати морфонологію СГ знаходимо в працях О. Кубрякової, Ю. Панкраца, Н. Ільїної, Т. Попової, М. Срмакової, Н. Ананьєвої (при описі слов' янської морфонології, зокрема субстантивної словозміни), С. Толстої (при описі морфонології словозміни та словотворення польської мови), М. Федурко (при описі морфонології відіменникового словотворення української мови), Г. Пристай (при описі морфонології відприкметникового словотворення української мови) та ін.

Новітні наукові спроби спрямовані на визначення сутності i функціональної значущості словотвірної морфонології, кваліфікації морфонологічних засобів, аналізі функцій різних типів альтернацій, установленні детермінантів морфонологічних перетворень у структурі похідних i встановленні морфонологічних класів відіменникових i віддієслівних словотвірних гнізд (СГ), визначенні функцій морфонологічних моделей, залучених до процесів словотворення, установленні структурних типів СП ЛСГ іменників, дієслів, виокремленні зон СП за частиномовною належністю дериватів та ін.

Є. Карпіловська зазначає, що з'ясування параметрів реалізації одиниць суфіксальної підсистеми уможливлює формулювання правил, яким підлягає функціонування іiі одиниць в актах породження морфемних структур слів певних типів [2, с. 7]. Суфіксальна граматика як проміжна ланка між підсистемою суфіксальних одиниць і продуктами іiі реалізаціїморфемними структурами реальних слів української мови - містить (ㄱ. М. Демешко, 2015. 


\section{СТРУКТУРА І СЕМАНТИКА МОВНИХ ОДИНИЦЬ}

правила, що поєднують опис принципів та способів організації й функціонування одиниць всередині підсистеми 3 описом принципів їхньго добору 3 інвентаря в певній формі та 3 певним змістом, розміщення в морфемній структурі слова й пристосування до внутрішньослівного оточення (лівих та правих партнерів у слові) [2, с. 8].

Унаслідок історичного розвитку української мови деякі дієслівні префікси мають кілька фонетичних варіантів. С. Соколова зауважує, що їхнє варіювання можливе лише в різних дієсловах або членах видової пари, якщо в них варіювання зазнає основа [5, с. 37]: (відійти - відходити, надійти - надходити, підійти - підходити; відганяти - відігнати; відгинати - відігнути). Варіювання префіксів від-/віді- зумовлене основою-мотиватором (віддирати - відідрати, відзивати - відізвати, відпихатися - відіпхнутися, відривати 1 - відірвати, відсилати відіслати, відтикатися - відіткатися), хоча можливе і вживання обох варіантів: відігравати - відгравати (недок.), відігрівати - відгрівати (недок.). У словниках зафіксовані варіанти префіксів віді-/ оді- 3 покликанням на основний варіант: відізватися - одізватися, відійти одійти, відімкнути - одімкнути, відіпхнути - одіпхнути, відіслати одіслати, відіспатися - одіспатися. Варіанти префіксів од-/одівживаються рідше, і дієслова з ними стилістично марковані, а в словниках подають їх 3 покликанням на основний варіант. Варіювання кінцевого префікса спричинене пристосуванням префікса до основи-мотиватора: до/ ді-, над-/ наді-, nid-/ nidi-, no-/ ni-: дізнавати - дознавати (недок.), дізнати - дознати (док., розм.); надсилати (недок.) - надіслати (док.).

Префікс з- має варіанти із-, зі-, зо-: зібгатися - зобгатися, зів'янути - зов'янути, зів'ялити - рідко зов'ялити, зів'ялий- зов'ялий; зганяти - зігнати, згинати - зігнути, зігнутий - рідко зогнутий, згинатися - зігнутися, зіграти - рідко зограти, зігрівальний зогрівальний; зводити - рідко ізводити, згадувати - рідко ізгадувати, звикати - рідко ізвикати.

Вибір варіанта префікса з- залежить від основ-мотиваторів, які однозначно співвіднесені 3 префіксами. Виняток становлять варіантні утворення, одне 3 яких основне, стилістично нейтральне, а решта стилістично марковані або рідковживані [5, с. 38]: зібгати - рідше зобгати, зів'янути - розм. зов'янути, зв 'ялити - рідко ізв'ялити, зов'ялити.

Варіанти о-/об- (обі-) перебувають у відношенні додаткової дистрибуції [6, с. 259], для яких частина значень спільна, а для деяких властива лише варіанту о-, об- (обі-): обпрядати (недок.) - обіпрясти (док., розм.), обриватися 1 - обірватися, обсилати - обіслати, обтинати 
- обітяти; обкреслити - окреслити, обкрутити - розм., рідко окрутити.

Функціонування варіантів префікса в- має певні семантичні особливості. Так, варіанти вві-/вi-/yвi- функціонують переважно в дієсловах зі значенням спрямування дії всередину об'єкта (крім дієслова ввірвати / увірвати). Близько 25 дієслів вживаються лише з префіксом $\boldsymbol{y}$ 3 результативним значенням: утворити, уникнути, діал. уйти; іноді вживається з фазовим значенням: увінчати, ухвалити, розм. укохати.

Отже, урахування всіх варіантів, зважаючи на формальносемантичні, омонімічні відношення на морфемному рівні, можливе за умов наявності кореневого гніздового словника з вершинним дієсловом (3 урахуванням варіативності коренів і варіативності афіксів - префіксів і суфіксів - у девербативах вербального, субстантивного, ад'єктивного й адвербіального блоків), що уможливить установлення семантичних відтінків і розбіжностей формальних варіантів.

У сучасній лінгвістиці накопичено цінний досвід теоретичного осмислення результатів аналізу будови та функціонування морфемної і словотвірної підсистем мов, зокрема суфіксальної підсистеми як найбільш розгалуженої й активної в слов'янськихї мовах [2, с. 3]. При виділенні суфіксальних одиниць дотримуємося коренезорієнтованого підходу, запропонованого у працях Г. Винокура, М. Панова, Є. Карпіловської, Н. Клименко, М. Федурко, Н. Янко-Триницької на противагу афіксозорієнтованому підходу, який обстоювали у своїх працях О. Смирницький, Л. Крисін та інші дослідники.

Чеський дослідник 3. Оліверіус зазначав, що основним критерієм класифікації морфем $є$ релятивна самостійність морфеми щодо інших морфем. Класифікація морфем утворює складну багатоступінчату ієрархію. Найважливішу проблему створює визначення межі між двома щаблями такої багатоступінчатої ієрархії [3, с.56]. Отже, для встановлення такої межі доцільно враховувати формально-семантичні, функціональні ознаки досліджуваних суфіксальних одиниць. Є. Карпіловська пропонує при визначенні типів суфіксальних одиниць враховувати такі ознаки: 1) тип основи (похідна (з вільною чи зв'язаною подільністю), непохідна подільна (оформлена чи не оформлена); 2) здатність самостійно виражати певне словотвірне (розрядне (часткове) чи категорійне (загальне) або граматичне (формотворне або частиномовне) значення чи виконувати допоміжну роль при конструюванні морфемної структури слова; 3) здатність самостійно формувати основу слова, тобто здатність виступати у визначальній для еталонних одиниць суфіксального класу позиції кінця основи слова [2, с. 15].

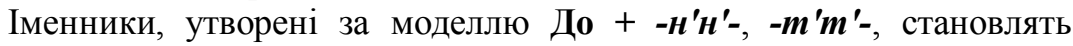
(ㄱ. М. Демешко, 2015. 


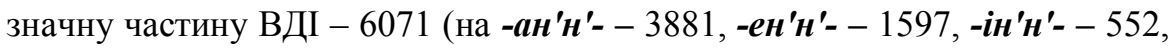
$-\boldsymbol{u н} \boldsymbol{H}^{\prime}-\mathrm{-41)}$.

При творенні похідних із суфіксом -ен' $\boldsymbol{\mu}^{\prime}-$ відбувається усічення дієслівної фіналі, можливі консонантні альтернації і зміна наголосу, а при творенні похідних із суфіксом -iн' $\boldsymbol{H}^{\prime}-$ відбувається усічення дієслівної фіналі, збереження або усічення в структурі іменника-мотиватора тематичного голосного основи дієслова-мотиватора недоконаного виду, можливі консонантні альтернації і зміна наголосу (становити становлення (в//вл), звабити - зваблення (б//бл); садити - садіння (д//д'), говорити - говоріння (p//p'), косити - косіння (c//c'), муркотати -

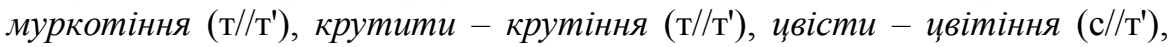
плести - плетіння $\left(\mathrm{c} / / \mathrm{T}^{\prime}\right)$. Консонантна альтернація $\mathrm{c} / \mathrm{T}^{\prime}$ виникла ще на праслов'янському грунті внаслідок дисимілятивних змін [1, с. 32].

Найбільш поширений варіант моделі До + -к- (1077) - основний: валка, нарізка, прядка, сушка, підтяжка - 1053). При цьому відбуваються регулярні чергування: $\boldsymbol{2}, \boldsymbol{\kappa}, \boldsymbol{x},-\boldsymbol{ж}, \boldsymbol{\varphi}, \boldsymbol{u}$ (підтягати $\rightarrow$ підтяжкка, балакати $\rightarrow$ балачка, задихатись $\rightarrow$ задишка); $\boldsymbol{m}-\boldsymbol{\varphi}($ світити $\rightarrow$ свічка). Тематичні голосні твірних основ у цьому варіанті втрачаються, а суфікси -yва-, -ва- зберігаються в усіченому вигляді (вишив|ка $\leftarrow$ вишива|ти). При чому суфікс -ува- представлений то елементом -ов- (кантовка кантувати), що пояснюється вПливом російських утворень на -ка чи прямим запозиченням з російської мови, то елементом -ів- (мандрівка манрувати), де -i- $\epsilon$ закономірною рефлексацією колишнього -о- в новозакритому складі. Менш поширені варіанти моделі До + -лк- (вія|лка, міси|лка -12). Не творяться іменники за моделлю До $+-\kappa-$ від основ, що мають у своєму складі префікси по-, на-, приєднані до префіксальних основ, які мають у своєму складі більше одного префікса (порозносити, навиготовляти, перевиховати, але перепідготовка).

За словотвірною моделлю До $+\boldsymbol{y} \boldsymbol{x}$ - утворено 58 іменників. Крім

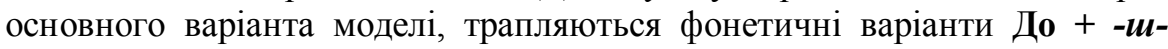
(колотуша, квакша). Виникнення варіантів із кінцевим шиплячим приголосним суфікса пов'язане 3 хитанням між твердим i м'яким варіантами відмін іменників (пор. колотуха - колотуша) та впливом російських утворень на -yш-. Основний варіант До $+\boldsymbol{y} \boldsymbol{y}$ - зустрічається найчастіше (балакуха, брехуха, колотуха - 49). Наголошений суфікс. У моделі функціонують переважно основи перехідних дієслів (квоктуха, вередуха - 46). Усі твірні основи - безпрефіксні, недоконаного виду. У моделі До + $\boldsymbol{y} \boldsymbol{x}$ - функціонують дієслівні основи різних структурних типів: основи на -a- (брех|уха $\leftarrow$ бреха|тu, різ|уха $\leftarrow$ різа|ти - 26); основа 


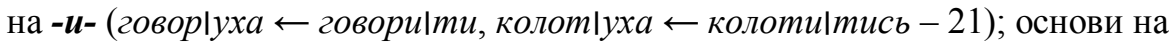
приголосний (волок|уша $\leftarrow$ волок|ти - 3); основи на -i- (лет|юха леті|ти - 2); основи із суфіксом -ува- (веред|уха єередува|ти, пуст|уха $\leftarrow$ пустува|ти - 3). У словотвірному акті фіналь дієслівної основи усікається, а тому деякі деривати співвідносяться 3 основами різних структурних типів (скреготуха $\leftarrow$ скреготіти, скреготати; лопотуха $\leftarrow$ лопотіти, лопотати - 3).

За моделю До + -л- утворено 77 іменників. У моделі функціонують лише основи дієслів недоконаного виду. Більшість твірних основ безпрефіксні (било, громило, калатало, кропило - 74). Лише три іменники (завивало, запинало, заткало) утворено від префіксальних основ. Твірними основами в цій моделі найчастіше бувають основи на -и(житло, бродило - 39) та основи на -а- (сідало, стійло - 33). Функціонування цієї моделі обмежується семантичними чинниками: не включаються в моделі дієслова, які корелюють за родами дії (здебільшого, це одновидові префіксальні дієслова на зразок носити / нести, поплавати); виняток становлять іменники стійло, сідло утворені від статальних дієслів [4, с. 57].

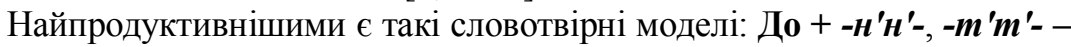
6071: знання, життя, злиття; До + -О - 1266: вижим, відгук, приїзд; До + -к- - 1077: нарізка, підтяжка, варка; До + -ник (-івник, -ильник) - 657: обхідник, рятівник, прядильник; До + -Ø(-а) - 521: довіра, хода, охорона, відміна; До + -ач - 340: наглядач, копач, командувач; До + -ок - 304: свисток, гудок, виток; До + -ець (-енець, -анець) - 180: борець, переселенець, мешканець; До + '-Ø - 82: зав'язь, дерть, відповідь; До + -л- 77: кропило, житло; До + -ун - 76: двигун, стрибун, опікун; До + -Ø(и) - 76: вибори, сходи, переговори; До + -тель - 73: учитель, повелитель, спаситель; До + -ин- - 43: дряпина, сходини; До + -к(и) - 63: висівки, гульки, носилки; До + -н'- (-арн'-, -івн'-, -ельн'-) - 59: лікарня, катівня, бительня; До + -иц'- (-ильниц'-, -івниц'-,) - 51: різниця, прядильниця, шатківниия; До + -н'- - 38: метушня, платня, лижня; До + -ищ- - 38: звалище, училище, судище; До + -ен-'- 37: учень, плавень, лежень, в'язень; До + -б- - 36: лічба, дружба, сівба, боротьба; До + -ій - 31: носій, водій, плаксій; До + -іж - 4: платіж, свербіж; До + -yx - 3: пастух, сплюх; Д + -уг- - 3: хапуга, волочюга; До + -ох- - 3: мандрьоха, забрьоха; До + -x- - 3: невдаха, заманиха; До + -ас - 3: ляпас, викрутас; До + -ур- - 2: замазура, таниңюра; До + -ін - 2: воїн, хазяӥн; До + -ог - 1: вертьог (вибоїна); До + -ог- - 1: вертьог(a) (посудина). Менш продуктивні словотвірні моделі віддієслівних іменників (ВДІ) сучасної української літературної мови ๑ І. М. Демешко, 2015. 
утворені за іншомовним словотвірним зразком: До + -mop, -атор - 78: організатор, дегустатор; До + -анm - 10: симулянт, емігрант; До + -ер 7: гример, гіпнотизер; До + -ент - 5: речензент, диригент; До + -yp- - 2: реєстратура, коректура; До + -ист - 2: публіичит. У межах ВДІ сучасної української мови функціонує 56 словотвірних моделей (7 моделей, запозичених з інших мов), кожна з яких має свою сферу функціонування.

Основні чинники, які обмежують або стимулюють функціонування моделей семантичного або структурного характеру. Семантичні чинники бувають двох видів 1. Чинники, що не мають формального вираження в основах дієслів: 1) лексичне значення твірних основ; 2) перехідність / неперехідність. 2. Такі, що мають формальне вираження в основах дієслів: 1) вид; 2) роди дії, властиві одновидовим дієсловам. До структурних чинників належать: 1. Структурний тип основ. 2. Структурні чинники, що не мають регулярної функції в плані змісту (морфонологічний аспект). Чинником, що обмежує функціонування моделей та їхніх варіантів, є характер фіналі основи дієслова.

Отже, системний характер відношень у розряді ВДІ сучасної української мови підкреслюють такі факти: 1) протиставлення словотвірних моделей у плані вираження відповідає протиставленню їхніх функцій у плані змісту; 2) при тотожності функцій різні в плані вираження словотвірні моделі різняться сферами функціонування; 3) при тотожності функцій і накладання сфер функціонування різних словотвірних моделей виникає конкуренція, що веде або до витіснення однієї моделі іншою, або до вужчої функціональної спеціалізації однієї з конкуруючих моделей.

Інвентар формальних трансформацій, що відбуваються на морфемному шві, переконує, наскільки морфонологічно значущішим є цей морфемний стик. Загальновідомо, що кожна частина мови має свій набір дериваційних суфіксів. Для морфонології релевантні передусім такі з них: 1) силабічність / асилабічність; 2) консонантний / вокалічний характер ініціалі; 3) довжина в морфонемах та їхнє аранжування; 4) наголошеність / ненаголошеність [7, с. 94]; 5) морфонологічна структура мотивувальної основи та словотворчого афікса; 6) будова контактної зони (останній склад основи) та ініціаль (зачин) форманта; 7) походження мотивувальної основи й суфікса (питомі/ запозичені); 8) акцентна маркованість / немаркованість суфіксів (аутоакцентні (обов'язково силабічні), преакцентні, постакцентні; акцентна потужність. Аутоакцентні суфікси віддієслівного словотворення субстантивного блоку: питомі: -ник,

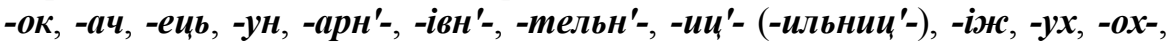
-іжк, -ог, -ур-; запозичені: -тор, -атор, -анm, -ер, -ур-, -ист. 
Аналіз морфонологічної будови елементарних суфіксів розпочнемо 3 одиниць на зразок VC. Слідом за Є. Карпіловською, елементарними вважаємо первісні, нерозкладувані на менші складники при вираженні певного категорійного або розрядного значення одиниці [2, с. 25]. Структуру VC має переважна більшість іменникових суфіксів - 21 проти виділених 56. Це зумовлено ще й структурою дієслівного кореня, консонантна фіналь якого вимагає в постпозиції вокальної морфонеми.

Серед прикметникових суфіксів різновид VC теж найпродуктивніший - 14 суфіксів із наявних 21 у досліджуваних словотвірних гніздах. У вокальній позиції домінують морфонеми $\{\boldsymbol{u}\}$, $\{\boldsymbol{o}\},\{\boldsymbol{e}\}$, а в консонантній - $\{\boldsymbol{M}\},\{\boldsymbol{\kappa}\},\{\boldsymbol{b}\},\{\boldsymbol{c m}\}-$ суфікси відповідно -им-, -ов-, -ев-, -ист-: род-им(ий), жит'm'-е́в(ий), жит'm'-ов(ий), розвісuст(ий); також продуктивний різновид CVC: нав'яз-лив(ий), гай-лив(ий), менш продуктивний різновид С: вит-к(úŭ), в'яз-к(úŭ). Таку формальну будову С1С2 мають суфікси -н'н'-, -m'm'-: склика́ння, скли́кання, читання, відкриття. Зрідка трапляються варіанти 3 подовженими кінцевими основи -л- та -д- (насилля, провалля, розладдя, угіддя, подовженим кінцевим шиплячим (подружжся, протиріччя).

Крім елементарних суфіксів, з дієслівними основами взаємодіють i кількаелементні інвентарні [1]. За формою вони бувають таких різновидів: CC, VCC, CVC, CCVC, VCVC: віша-лк(a), вит-у́шк(a) (прилад), пове-д-інк (a), бит-ельн'(a), розвід-ник, володі-льник, воз-увень.

Дієслівні суфікси в морфонологічному аспекті різняться від іменних характером облігаторного компонента, меншою потужністю використання потенцій фонологічної системи мови. Основною формою цього класу словотворчих морфем є форма V. Ї̈і мають суфікси $-\boldsymbol{a}-:$ відділ-u-mu - віддi$л^{\prime}-\dot{a}-m u$, дозвол-и-mu - дозвол'-́́-mu - при формотворенні. Високою продуктивністю характеризується суфікс -ува- (VCV): довикон-ува-ти.

Отже, афікси віддієслівних словотвірних гнізд неоднорідні з погляду морфонологічної структури, більшим розмаїттям відзначаються суфіксальні морфеми. Установлено, що фінальні елементи дісслівної основи, які зазнають змін під впливом ініціалі форманта, сигналізують про можливі морфонологічні операції (усічення, консонантні, вокалічні альтернації, нарощення суфіксальної чи кореневої морфем, модифікації наголосу) у віддієслівному похідному. Кожна морфонологічна зміна на морфемному шві відбувається за наявності відповідних умов. Девербативи в СГ утворені за відповідними словотвірними i морфонологічними моделями. Морфонологічні альтернації розширюють валентні властивості словотворчих морфем, уможливлюють творення похідних будь-якого (ㄱ. М. Демешко, 2015. 
блоку, збагачують інноваційні ресурси сучасного лексикону.

Перспективу подальшого дослідження словотвірної морфонології девербативів убачаємо у визначенні особливостей структури словотвірних гнізд з вершинними дієсловами на групу приголосних.

\section{Література}

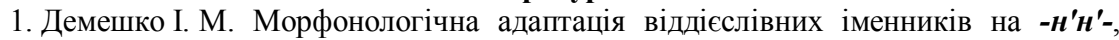
- $\boldsymbol{e H}^{\prime} \boldsymbol{H}$ '- у сучасній українській літературній мові / І. М. Демешко // Науковий вісник Херсонського держ. ун-ту. - Серія : Лінгвістика. - Вип. III. - Херсон, 2006. - С. 29-34.

2. Карпіловська Є. А. Суфіксальна підсистема сучасної української літературної мови : будова та реалізація : [монографія] / Є. А. Карпіловська. - К., 1999. - 297 с.

3. Оливериус 3. Ф. Морфемный анализ русского языка / 3.Ф. Оливериус // Проблемы современной лингвистики. - Praha : Univ. Karl., 1967. - С. 9-78.

4. Пінчук О. Ф. Словотвірна структура віддієслівних іменників сучасної української літературної мови / О.Ф. Пінчук // Морфологічна будова сучасної української мови. - К. : Наукова думка, 1975. - С. 35-82.

5. Соколова С. О. Префіксальний словотвір дієслів у сучасній українській мові : [монографія] / С. О. Соколова. - К. : Наукова думка, 2003. - 284 с.

6. Словотвір сучасної української літературної мови / АН УРСР. Ін-т мовознавства ім. О. О. Потебні. - К. : Наукова думка, 1979. - 408 с.

7. Федурко М. Ю. Морфонологія відіменникового словотворення : [монографія] / М. Ю. Федурко. - Київ-Дрогобич : Вимір, 2003. - 271 с.

Стаття надійшла до редакиії 01.07.2015 p. 